\title{
New Russian legislative approaches and navigational rights within the Northern Sea Route (NSR)
}

This is the earlier version of the article published in The Yearbook of Polar Law Vol 12,

2020 by Brill Nijhoff.

Jan Jakub Solski ${ }^{\mathrm{a}}$

${ }^{a}$ Norwegian Centre for the Law of the Sea, UiT - the Arctic University of Norway, Troms $\phi$, Norway

\section{Abstract:}

The regulation of foreign navigation in the Northern Sea Route (NSR) has been dominated by the rules of international law applicable to merchant ships only.

Neither the domestic set of rules of navigation on the NSR, based on Article 234 of UNCLOS nor the Polar Code applies to State-owned vessels. While the application of Article 234 has so far let Russia evade discussion on the navigational rights, one can expect an increasing spotlight on this issue. In response to the recent crossing of the NSR by a French warship, as well as the voices from the United States indicating similar plans, Russia has signaled the intention to adopt more stringent rules for passage of warships, potentially including the requirement of prior notification and pilotage.

The aim of the paper is twofold. First, examine the navigational rights as applicable in the NSR. As such, the paper will discuss historical State practice and relevant international law to demonstrate, among other things, that the enclosure with straight baselines preserved innocent passage in all Russian Arctic straits. Second, examine the international legality of prior notification and pilotage in the context of the applicable navigational rights on the NSR. 


\section{Introduction ${ }^{1}$}

In September 2018, the French Navy's new offshore support and assistance vessel, the Rhône (A603), transited the Northeast Passage (NEP), ${ }^{2}$ starting in Troms $\varnothing$, Norway, 1 September and ending in Dutch Harbor, Alaska, on 17 September. ${ }^{3}$ There is little

${ }^{1}$ This paper draws from the earlier work of the author, specifically J. J. Solski, "Navigational rights of warships through the Northern Sea Route (NSR) - all bark and no bite?", The JCLOS Blog 2019, https://site.uit.no/nclos/2019/05/31/navigational-rights-of-warshipsthrough-the-northern-sea-route-nsr-all-bark-and-no-bite/ [22 January 2020]; and J. J. Solski, "Russia" in R., C. Beckman, T. Henriksen, K. D. Kraabel, E. J. Molenaar and J. A. Roach, Governance of Arctic Shipping: Balancing Rights and Interests of Arctic States and User States (Brill Nijhoff 2017).

${ }^{2}$ The notion of the NSR (Severnyi Morskoj Put') was conceptualized in the early years of the Soviet Union to assist the northern delivery of goods into the Soviet Arctic settlements and shipping the resources out of the Arctic, and to a lesser degree as a trans-Arctic passage between Soviet ports. The latter objective relates closely to the vision behind the international concept of the Northeast Passage (NEP) as an Arctic corridor linking Atlantic and Pacific ports. The two notions developed somewhat independently alongside one another, and without clear specification regarding what exactly each entailed. Since 1932, Soviet and Russian legislation has included a few different and, until 2012, imprecise definitions of the NSR. See Section 2 below for the currently applicable and clear definition of the NSR.

${ }^{3}$ Atle Staalesen, "Izvestia: This is what awaits foreign military vessels on Northern Sea Route", The Barents Observer, 7 March 2019, https://thebarentsobserver.com/en/security/2019/03/izvestia-what-awaits-foreign-militaryvessels-northern-sea-route [21 January 2020]. 
explicit information available as to whether the vessel coordinated its plans with Russian authorities beforehand, but Russian sources refer to the voyage as conducted "without warning". ${ }^{4}$ The vessel navigated independently,${ }^{5}$ without icebreaker assistance or pilotage, although the Russian news agency Interfax informs that it was "monitored" by the radio intelligence equipment of the Northern and Pacific fleets in their areas of responsibility in the Russian Arctic. ${ }^{6}$

Over the past years, different signals have been coming from another NATO member State, the United States, ${ }^{7}$ indicating the US objections and concerns regarding Russia's NSR regulatory scheme, and, more recently, its readiness to take concrete action by transiting the Russian Arctic with surface vessels as part of the US Freedom

${ }^{4}$ Aleksej Kozachenko, Bogdan Stepovoj, Jel'nar Bajnazarov, "Holodnaja volna: inostrancam sozdali pravila prohoda Sevmorputi: Voennym korabljam i sudam pridetsja uvedomit' Rossiju o svoih planah za 45 sutok", Izvestya, 6 March 2019, https://iz.ru/852943/alekseikozachenko-bogdan-stepovoi-elnar-bainazarov/kholodnaia-volna-inostrantcam-sozdalipravila-prokhoda-sevmorputi [21 January 2020].

${ }^{5}$ AFP, “Arctique: le passage Nord-Est franchi pour la première fois par la Marine”, Franceinfo, 2 October 2018, https://france3-regions.francetvinfo.fr/bretagne/finistere/brest/arctiquepassage-nord-est-franchi-premiere-fois-marine-1551014.html [21 January 2020].

${ }^{6}$ Interfax, “Korabl NATO vpervye proshel Severnym morskim putem”, 2 October 2018, https://www.interfax.ru/world/631532 [21 January 2020].

${ }^{7}$ United States of America, Diplomatic Note from the United States to Russia regarding the NSR (29 May 2015) reproduced in CarrieLyn D. Guymon (ed), Digest Of United States Practice In International Law 2015, p. 526, https://20092017.state.gov/documents/organization/258206.pdf [21 January 2020]. 
of Navigation Program. ${ }^{8}$

In November 2018, Mikhail Mizintsev, the Head of the Russian National Defense Management Center pledged that by the start of the 2019 navigational season foreign warships would only be able to navigate the NSR following prior notification. ${ }^{9}$ According to his statement, new legislative developments were supposed to fill the legal vacuum regarding the use of the NSR. In March 2019, a Draft Resolution of the Government of Russia was published on the website of the Government. ${ }^{10}$

The draft legislation, prepared by the Russian Ministry of Defense, targets foreign warships and other vessels operated by a State and used on non-commercial service to the extent that they exercise the right of innocent passage in the territorial sea of the NSR. The draft would require:

- The flag State to submit a notification concerning the planned passage through the territorial sea of the Russian Federation in the NSR no later than 45 days before the start of the proposed passage;

${ }^{8}$ David Auerswald, "Now is not the time for a FONOP in the Arctic", War on the Rocks, Texas National Security Review, 11 October 2019, https://warontherocks.com/2019/10/now-is-notthe-time-for-a-fonop-in-the-arctic/ [21 January 2019].

${ }^{9}$ Interfax, "S 2019 goda voennye korabli smogut khodit po Sevmorputi tolko uvedomiv RF", 30 November 2018, https://www.interfax.ru/russia/640154 [21 January 2020].

${ }^{10}$ Draft Resolution of the Government of Russia on Amendments to the Resolution of the Government of Russia No. 1102, 2 October 1999, "On the rules of navigation and presence of foreign warships and other state-owned ships operated for non-commercial purposes in the territorial sea, internal waters, on naval bases, and bases for stationing warships in seaports of the Russian Federation, https://regulation.gov.ru/projects\#npa=89000 [21 January 2020]. 
- The ship to use the service of mandatory ice pilotage in the territorial sea and internal waters of the NSR;

- The ship to use icebreaker assistance in the territorial sea and internal waters of the NSR if necessary.

Besides, the draft proposes that foreign warships exercising innocent passage "must have the necessary ice construction, observe special precautionary measures and comply with the requirements relating to the safety of navigation and protection of the marine environment from pollution from ships (as applicable to the waters of the Northern Sea Route).”

Ironically, the recent tension over the applicable regime of navigation through the NSR has arguably arisen, at least in part, due to the liberalization of Russian legislation on navigation there. The 2012 Federal Law ${ }^{11}$ introduced into the 1999 Merchant Shipping Code ${ }^{12}$ Article 5.1, entitled "navigation in the water area of the NSR". This provision became central to the legal regime of the NSR. It provides, among other things, the definition of the NSR and calls for the adoption of rules of

${ }^{11}$ Federal Law on Amendments to Specific Legislative Acts of the Russian Federation Concerning the State Regulation of Merchant Shipping in the Water Area of the NSR, 28 July 2012, No. 132 FZ, Sobranie zakonodatel'stva Rossiyskoy Federatsii 30 July 2012 No. 31 p. 4321 (2012 Federal Law).

${ }^{12}$ The Merchant Shipping Code of the Russian Federation], 30 April 1999, No. 81 FZ, Sobranie zakonodatel'stva Rossiyskoy Federatsii 3 May 1999 No. 18 p. 2207 (1999 Merchant Shipping Code). 
navigation. In as much as the 2013 Rules of Navigation in the NSR (2013 Rules) ${ }^{13}$ are legally based on Article 5.1(2), other provisions of the 1999 Merchant Shipping Code limit their scope of application ratio personae. Pursuant to Article 1, the 1999 Merchant Shipping Code applies only to relations arising from merchant shipping; Article 3(2) explicitly excludes its application to State-owned vessels.

The decision to anchor the 2013 Rules in the 1999 Merchant Shipping Code, thus rendering the 2013 Rules applicable only to commercial ships, deserves appreciation as a departure from the earlier policy of non-discrimination between commercial and State-owned vessels. The 1990 Regulations ${ }^{14}$ applied to all ships, which was inconsistent with Article 236 of the United Nations Convention on the Law of the Sea (UNCLOS). ${ }^{15}$ According to Article 236, the provisions of UNCLOS regarding the protection and preservation of the marine environment "do not apply to any warship, naval auxiliary, other vessels or aircraft owned or operated by a State and used, for the time being, only on government non-commercial service". A flag State is required to adopt appropriate measures not impairing the operational capabilities of such vessels to ensure that they act in a manner consistent with the Convention, but only

${ }^{13}$ Rules of Navigation in the Water Area of the Northern Sea Route, as approved by the order of the Ministry of Transport of Russia, 17 January 2013 № 7, registered by the Ministry of Justice 2 April 2013 No. 28120 (2013 Rules).

${ }^{14}$ The 1990 Regulations for Navigation on the Seaways of the Northern Sea Route, approved on 14 September 1990], published on 18 June 1991 in 29 Izveshcheniya Moreplavatelyam (1990 Regulations).

${ }^{15}$ D. R. Brubaker, Environmental Protection of Arctic Waters - Specific Focus the Russian Northern Sea Route (Doctoral Thesis, University of Stockholm 2002): 299-300. 
so far as is reasonable and practicable. Furthermore, it follows from Article 30 of UNCLOS that warships are required to comply with laws and regulations of the coastal State concerning passage through the territorial sea, but other than that, Article 32 reaffirms the immunity of warships and other government ships operated for noncommercial purposes. A joint interpretation of the three provisions suggests that sovereign immune vessels may be obliged to comply with laws and regulations of a coastal State as long as they are lawful, i.e., permissible in the territorial sea, and applicable, i. e., not regarding the protection and preservation of the marine environment.

This leads to the main question this article aims to address, namely, what are the applicable navigational rights in the NSR, and where exactly do they apply? In Russia, there exists a particular discourse, as reflected in academic writings and statements by politicians, which creates the impression that the NSR is a national asset because of the sacrifices made to develop it. ${ }^{16}$ This perception seems to have laid the groundwork for the determination of the NSR as a "historically developed national transport line of communication of the Russian Federation". ${ }^{17}$ Yet, the geographical scope and substantive extent of coastal State jurisdiction, as well as concomitant navigational rights and freedoms within the NSR, are determined by international law.

${ }^{16}$ See J. J. Solski, "New developments in Russian regulation of Navigation on the Northern sea route" 1 Arctic Review on Law and Politics 90 (2013): 103-107.

${ }^{17}$ Currently included in Article 14 of the Federal Law On the internal sea waters, territorial sea and contiguous zone of the Russian Federation], 31 July 1998, No. 155-FZ, Sobranie zakonodatel'stva Rossiyskoy Federatsii 3 August 1998 No. 31 p. 3833 (1998 Federal Law on the IWTSCZ). 
In practice, Russia's measures with the official purpose of ensuring maritime safety and environmental protection in the Arctic, broadly associated with Article 234, blurred the distinction between a right and privilege. The recent developments in Russian State practice, such as the recognition for the distinction between merchant and sovereign immune vessels, and the clarification of the international legal basis for the 2013 Rules, ${ }^{18}$ have been helpful to isolate the question of the applicability of navigational rights from the overshadowing effect that jurisdiction exercised pursuant to Article 234 might have. This issue is not only of fundamental and current relevance for sovereign immune vessels. After all, the powers enshrined in Article 234 depend on the specific characteristics of the physical environment. This article will not deal with the question of Article 234's (in-) applicability in the areas that no longer qualify as 'icecovered' for most of the year because of climate change, but one should be mindful of such possibility.

The remainder of the paper is structured as follows. Section 2 briefly presents the current legal status of the NSR. Section 3 gives an overview of Russia's relevant historical practice to support the conclusions on its effects on navigational rights in Section 4. Section 5 deals with prior notification and pilotage under the international law of the sea. The paper ends with conclusions in Section 6.

${ }^{18}$ The clarification that the 2013 Rules are "adopted and enforced by the Russian Federation in accordance with Article 234 of UNCLOS" came from the Ministry of Transport of the Russian Federation, Federal Agency for Sea and Inland Water Transport, Administration of the NSR, 'Notification No. 77', 20 September 2013, http://www.nsra.ru/files/zayavka/20130920143952ref\%20A\%20S.pdf [21 January 2020]. 


\section{The Northern Sea Route}

Article 5.1 of the 1999 Merchant Shipping Code defines the NSR as:

[A] water area adjoining the northern coast of the Russian Federation, including internal sea waters, territorial sea, contiguous zone and exclusive economic zone of the Russian Federation, and limited in the East by the line delimiting the sea areas with the United States of America and by the parallel of the Dezhnev Cape in the Bering Strait; in the West, by the meridian of the Cape Zhelanie to the Novaya Zemlya archipelago, by the east coastal line of the Novaya Zemlya archipelago and the western limits of the Matochkin Shar, Kara Gates, Yugorski Shar Straits.

As such, Russian legislation recognizes that the NSR consists of internal waters, territorial sea, contiguous zone, and exclusive economic zone (EEZ). ${ }^{19}$ Moreover, it is not controversial or disputable that under international law, other States within the NSR enjoy the right of innocent passage in the territorial sea and the freedom of navigation in the EEZ. A somewhat more controversial issue arises concerning the applicable navigational rights through different straits enclosed within straight baselines in the 1985 Decree on Baselines. ${ }^{20}$ These include the following straits: Matochkin Shar, Kara Gates and Yugorskii Shar connecting the Barents Sea with the Kara Sea; the Vilkitsky, Shokalsky, Red Army and Yungshturm Straits connecting the Kara and Laptev Seas; the Dimitri Laptev and Sannikov Straits connecting the Laptev and East Siberian Seas.

${ }^{19}$ Notably, under this new definition the NSR does not extend beyond $200 \mathrm{~nm}$ from Russia's baselines. This is quite an important novelty, since the 1990 Regulations were ambiguous concerning the northern limits of the NSR. See Solski, note 16: 95-96 for a discussion on this matter.

${ }^{20}$ Russia, The USSR Council of Ministers, Decree of 15 January 1985 , http://www.un.org/Depts/los/LEGISLATIONANDTREATIES/PDFFILES/RUS_1985_Decl aration.pdf [21 January 2020] (1985 Decree on Baselines). 
The Long Strait, which connects the East Siberian and the Chukchi Seas, has not been enclosed with a straight baseline.

Assuming, but only for the sake of argument, that Russian straight baselines are valid, the legal status of waters landward of baselines is that of internal waters. Under the law of the sea, there are three possible scenarios regarding the applicable navigational rights in these waters. The first one is that no right of navigation exists, ${ }^{21}$

${ }^{21}$ Russian international law authors seldom discuss this question, but when they do, that is the position they take. Note that V. V. Gavrilov, "Legal Status of the Northern Sea Route and Legislation of the Russian Federation: A Note" (2015) 46 Ocean Development and International Law 256: 260 asserts, "[w]ith respect to those areas of the NSR that are within the internal waters of Russia, the area is under the complete sovereignty of the Russian Federation". V. Golitsyn, "The Legal Regime of the Arctic" in D. J. Attard (general ed), M. Fitzmaurice, Norman A. Martinez Gutierrez (eds), The IMLI Manual on International Maritime Law: Volume I: The Law of the Sea (Oxford University Press 2014): 471-472 states that the position of the USSR at the time of the adoption of the 1985 Decree on Baselines was that none of the straits had been used for international navigation and the right of innocent passage was not preserved. More recently, P. Gudev, "The Northern Sea Route: a National or an International Transportation Corridor?", Russian International Affairs Council, 24 September 2018, concludes his analysis of the exchange of notes between the USSR and the United States in the 1960s, as well as the 1985 Decree on Baselines with the observation that the latter "made it possible to declare the Vilkitsky, Shokalsky, Laptev, Sannikov and Kara Straits historical internal waters of the USSR". 
the second one that innocent passage has been preserved, the third one that at least some of these straits are subject to the right of transit passage. ${ }^{22}$

The following sections aim to analyse Russia's historical practice and its effect on the status of waters, as well as the existence of navigational rights.

\section{Overview of Russia's historical 'tools and claims' affecting 'control' over the NSR.}

\subsection{Russia's de facto control of navigation in the NSR}

The primary obstacle hindering the NEP from becoming of genuine significance for global maritime trade has been the presence of ice, remoteness, and otherwise challenging navigational conditions. The Arctic has been used for navigation for centuries, although not so in the form of transits between ports in the Atlantic and Pacific Oceans.

Furthermore, Soviet and Russian practice over nearly ninety years of the existence of the NSR has been guided by the objective of keeping the Arctic straits for national use, and under national control. When offers were made to foreigners to use the NSR, the first in 1967, repeated by Gorbachev in 1987, and set out in the 1990

${ }^{22}$ This is a position taken by the United States, see 2015 US Diplomatic Note to Russia, note 7

"to the extent that the Northern Sea Route scheme continues the view of the Russian Federation that certain straits used for international navigation in the Northern Sea Route are internal waters of the Russian Federation, the United States renews its previous objections to that characterization." 
Regulations, it was presupposed that the coastal State remained in charge of the route's administration and that the users would pay for the services provided. ${ }^{23}$

Moreover, during the Soviet era, foreign merchant vessels could effectively only operate in the NSR under charter with Soviet trade organizations. ${ }^{24}$ Coastal trade between ports - cabotage - was under the 1929 Merchant Shipping Code of the USSR, ${ }^{25}$ and later the 1968 Merchant Shipping Code of the USSR, ${ }^{26}$ reserved only for Soviet vessels. ${ }^{27}$ While both the 1929 Merchant Shipping Code and the 1968 Merchant Shipping Code distinguished between "small" 28 and "large" 29 cabotage, both types of transport were allowed for Soviet vessels only. As such, navigation between the port of

${ }^{23}$ J. J. Solski, "Russia” in R., C. Beckman, T. Henriksen, K. D. Kraabel, E. J. Molenaar and J. A. Roach, Governance of Arctic Shipping: Balancing Rights and Interests of Arctic States and User States (Brill Nijhoff 2017): 180.

${ }^{24}$ W. E. Butler, Northeast Arctic Passage (Sijthoff \& Noordhoff 1978): 61.

${ }^{25}$ Article 71 of the Merchant Shipping Code of the USSR], 14 June 1929, Sobraniye zakonov SSSR, 1929, No. 41, p. 366.

${ }^{26}$ Article 2 of the Merchant Shipping Code of the USSR], 17 September 1968, Vedomosti VS SSSR, 1968, No. 39, p. 351.

${ }^{27}$ Butler, note 24: 98-99.

${ }^{28}$ In principle, small cabotage referred to transport between ports of one sea. However, the Arctic Ocean and the White Sea were regarded as one sea; as such, navigation between all Soviet Arctic ports would qualify as "small" cabotage, regardless of the fact, that such navigation could pass through up to five different seas: the White, Barents, Kara, Laptev, East Siberian and Chukchi Seas.

${ }^{29}$ Large cabotage would denote transport between Soviet ports in different seas. 
Saint Petersburg and Vladivostok would still be considered cabotage, despite the ship would have to pass many different seas.

In essence, if a foreign commercial ship were to navigate through the NEP, its initial port or the port of destination would have to be a foreign port. Besides, most Soviet Arctic ports were closed to foreign vessels at different times. ${ }^{30}$ Therefore, as the right of cabotage between Soviet ports was restricted to Soviet ships, and navigation without the use of Soviet icebreakers was unlikely, there was little incentive for foreign companies to engage in shipping through these waters in a way that would challenge Soviet legislation. Both natural conditions and the official approach were not conducive to the international use of the NSR.

The number of foreign-flagged vessels traversing the entire NEP demonstrates this reality. The few occurrences of foreign ships transiting the NEP include the voyage by the Vega in 1878-79, or later the Maud in 1918-19, both taking place before the official commencement of the NSR's development, and before the USSR came to be. Against this background, Franckx describes the 1991 trip of the Astrolabe - not only allowed by the Russian authorities but also conducted with their active participation - as the first circumnavigation of the Eurasian continent by a Western ship since the early 1920s. ${ }^{31}$ As such, the NSR has not been utilized by foreign ships, warships, and

${ }^{30}$ G. N. Semanov, "Legal and Environmental Evaluation of Selected Routes along the Northern Sea Route” in C. L. Ragner (ed), The 21st Century - Turning Point (Springer 2000): 98, refers to only the port of Igarka that would normally be open for foreign vessels, but the list of open ports in the Russian Arctic was updated annually.

${ }^{31}$ E. Franckx, "The Soviet Maritime Arctic, Summer 1991: A Western Account" (1992) 1 Journal of Transnational Law and Policy 131:141. One may also take note of the somewhat 
commercial ships, until its 'official opening' in 1991, or more precisely the navigational season of 2010 - the first one that featured the international use of the NSR for commercial purposes, preceded by the exploratory voyages of the MV Beluga Fraternity and the MV Beluga Foresight in $2009 .{ }^{32}$ Since then, all voyages were conducted with the explicit permission of the Russian authorities, granted within the frameworks set up first by the 1990 Regulations, and later by the 2013 Rules. In this regard, the circumnavigation of the entire NEP by the Rhône (A603) without Russian coordination appears remarkable.

It is, therefore, evident that the NSR has remained under the control of the USSR/Russia for decades. Adding to the physical environment and the practical effect of cabotage laws, the policy was successful due to other tools and practices targeting ships in the lateral passage as well. This article systematizes these three pillars as follows. The first related to the controversial Soviet policy regarding the problematic interpretation of innocent passage. The second involved the adoption of straight baselines. The third, predominant one, has been based on measures with the official purpose of ensuring maritime safety and environmental protection.

exceptional trip of the German auxiliary cruiser the Komet in 1940, conducted with the approval of the USSR and with use of its icebreakers, during World War II.

${ }^{32}$ E. Franckx and L. Boone, "New Developments in the Arctic: Protecting the Marine Environment from Increased Shipping" in M. H. Nordquist, J. N. Moore, A. H. A. Soons and Hak-So Kim (eds), The Law of the Sea Convention: US Accession and Globalization (Maurtinus Nijhoff Publishers 2012): 188-190. 


\subsection{Territorial sea and innocent passage in the Arctic: early perspectives}

Once the USSR established a $12 \mathrm{~nm}$ belt of territorial sea for the first time in the 1960 Statute ${ }^{33}$ its Article 15 qualified the right of innocent passage by the requirement that “(...) passage shall be considered innocent if the vessel follows a customary navigational course or a course recommended by competent agencies (...)". ${ }^{34}$ It is important to note that the 1958 TSCZ Convention did not include any such qualification for the innocence of passage. ${ }^{35}$

However, the lack of recognition of the right of innocent passage for warships in the 1960 Statute was more controversial. ${ }^{36}$ Article 16 provided for a procedure of authorization, ${ }^{37}$ specified by a requirement on warships to seek at least 30 days in advance and obtain prior authorization to pass the territorial sea.

This requirement was consistent with the Soviet position for which they sought international recognition unsuccessfully during UNCLOS II in $1960 .{ }^{38}$ The USSR

${ }^{33}$ Statute on the Protection of the State Border of the USSR], 5 August 1960, Vedomosti VS RSFSR, 1960, No. 31 (1960 Statute).

${ }^{34}$ Ibid.

${ }^{35}$ See Article 14 of the Convention on the Territorial Sea and the Contiguous Zone (adopted 29 April 1958, entered into force 10 September 1964) 526 UNTS 205 (1958 TSCZ Convention).

${ }^{36}$ See, generally, E. Franckx, "Innocent Passage of Warships: Recent Developments in USSoviet Relations" (1990) 14 (6) Marine Policy 484.

${ }^{37}$ Article 16 of the 1960 Statute.

${ }^{38}$ For example, Franckx, note 36, p. 485. 
attached a reservation to its instrument of ratification of the 1958 TSCZ Convention, ${ }^{39}$ which stipulated that the USSR interpreted international law in a manner such that a coastal State had a right to establish an authorization procedure for the passage of foreign warships through its territorial sea. ${ }^{40}$ Although the USSR openly reserved its rights, the reservation appears to have been contrary to the object and purpose of the 1958 TSCZ Convention, and thus unlawful. ${ }^{41}$

The 1982 Law on State Boundary of the USSR (1982 Law) ${ }^{42}$ introduced a change in the Soviet approach to innocent passage. An improvement was that Article 13 of the 1982 Law provided for a right of innocent passage for both merchant vessels and warships. However, the legislation continued the qualification of innocent passage of merchant ships by insisting that the vessels follow the "customary navigational course or a course recommended by competent agencies'. ${ }^{43}$

To implement the $1982 \mathrm{Law}$, the 1983 Rules $^{44}$ set out a specific procedure for the exercise of innocent passage by warships. Article 12 of the 1983 Rules permits the

${ }^{39}$ The USSR ratified the 1958 TSCZ Convention after UNCLOS II on 22 November 1960.

${ }^{40}$ D. Pharand, "Soviet Union Warns United States against Use of Northeast Passage" (1968) 62 (4) American Journal of International Law 927: 933.

${ }^{41}$ Ibid: 934.

${ }^{42}$ Law on State Boundary of the USSR], adopted 24 November 1982, Vedomosti VS SSSR, 1982, No. 48, p. 891 (1982 Law).

${ }^{43}$ Article 13 of the 1982 Law.

${ }^{44}$ Russia, 1983 Rules Concerning Navigation and Sojourn of Foreign War Vessels in the Territorial Waters of the USSR, the Internal Waters of the USSR and Ports of the USSR, 34 Notices to Mariners, pp. 42-47 
innocent passage of warships by using lanes, customarily used for international navigation.

Further, Article 12 of the 1983 Rules listed existing traffic separation schemes in the Baltic Sea, the Sea of Okhotsk and the Sea of Japan. The omission of the Arctic stirred questions on the policy of the USSR on the innocent passage of warships in the Arctic. ${ }^{45}$ It was not clear whether the list was intended to be exhaustive, meaning that innocent passage was not allowed elsewhere; or, as an alternative, that in areas not mentioned, the usual international rules applied. ${ }^{46}$

The Black Sea incident in 1988 made it clear that the USSR favored the former interpretation. The US Navy sent ships to the Black Sea in 1986 and in 1988 to navigate in the territorial sea south of the Crimean Peninsula. ${ }^{47}$ In response to the second incident, the USSR provided an explicit position, favoring a restrictive interpretation of Article 12 of the 1983 Rules. ${ }^{48}$ From this, one can infer that the USSR intended to allow innocent passage of warships in some parts of its territorial sea. ${ }^{49}$

${ }^{45}$ See, for instance, E. Franckx, "Non-Soviet Shipping in the Northeast Passage, and the Legal Status of Proliv Vil'kitskogo" (1988) 24 (151) Polar Record 269: 272-273.

${ }^{46}$ Ibid.

${ }^{47}$ E. Franckx, Maritime Claims in the Arctic: Canadian and Russian Perspectives (Martinus Nijhoff Publishers 1993): 165-166.

${ }^{48}$ Franckx, note 47: 166, reproduces the communication of the USSR that reads: “(...) According to existing Soviet rules, foreign warships only enjoy such right [innocent passage] in places where sea lanes for international navigation are established (...)".

${ }^{49}$ Ibid. 
However, as this position explicitly addressed the innocent passage of warships, it did little to clarify the enigmatic qualification of innocent passage of merchant ships. It is possible that the USSR would have indicated that there was no customary navigational course through its Arctic straits, and as such, innocent passage would not be recognized. Yet when an occasion to do so arose, when the US Coast Guard's vessels intended to cross the Vilkitsky Strait in August 1967, the USSR chose not to argue that the right of innocent passage did not apply. The Soviets successfully discouraged the vessel from proceeding, but the emphasis was made on the requirement of prior authorization for warships, and not on the non-applicability of innocent passage in the Vilkitsky Strait. ${ }^{50}$ If the USSR had chosen to argue that innocent passage did not apply, this would have been inconsistent with the 1958 TSCZ Convention, which recognizes the right of innocent passage with no qualification as to the historical exercise of the right. Likely, other States would not have accepted such an assertion.

The Soviet stance on the application of innocent passage for merchant vessels in the Arctic straits overlapping with the territorial sea until 1985 was never tested. When the Astrolabe navigated the NSR in 1991, the legal regime for navigation in the NSR was based on the other two pillars of Soviet/Russian practice: straight baselines and the requirement of prior authorization under the 1990 Regulations.

Crucially, in 1989, the United States and the USSR reached a compromise with the 1989 USSR-USA Joint Statement, including the Uniform Interpretation of Norms of

${ }^{50}$ Russia, "Aide Memoire from the Soviet Ministry of Foreign Affairs to the American Embassy Moscow”, American Embassy Moscow telegram 754, 24 August 1967, as reproduced in J. A. Roach and R. W. Smith, Excessive Maritime Claims (3rd edn, Martinus Nijhoff Publishers 2012): 315. 
International Law Governing Innocent Passage. This marked a change in the Soviet approach to innocent passage, recognizing its application in the territorial sea regardless of the adoption of sea lanes, TSSs or the existence of a 'customary navigational course'. 51

\subsection{Do Russian straight baselines delineate historic waters in any of the NSR straits?}

It seems likely that the only valid argument supporting the view that the waters in straits had been considered internal waters before the establishment of straight baselines would be that Russia has successfully made a historic waters claim in respect of them. The 1985 Decree, includes the only list of historic waters claims explicitly made by Russia in the Arctic. It refers to only three areas: the White Sea, the waters of Cheshskaya Bay, and only one bay located within the NSR - the Baidaratskaya Bay, as waters "historically belonging to the USSR, internal waters". 52

Admittedly, in 1964 the USSR explicitly referred to the Laptev and Sannikov Straits as "historically belonging to the USSR". In response to the intention of the US vessel Burton Island to traverse the Dmitry Laptev and Sannikov Straits in 1964, the Soviet Ministry of Foreign Affairs presented the Aide Memoire to the USA, which stipulated that the Dmitry Laptev and Sannikov Straits belong historically to the Soviet Union. The relevant passage reads:

${ }^{51}$ Paragraphs 2 and 5 of the Union of Soviet Socialist Republics - United States of America: Joint Statement with attached uniform Interpretation of Rules of International Law governing Innocent Passage (23 September 1989) (1989) 28 International Legal Materials 1444 (1989 USSR-USA Joint Statement).

${ }^{52}$ The 1985 Decree. 
It should also be kept in mind that the northern seaway route at some points goes through Soviet territorial and internal waters. Specifically, this concerns all straits running west and east in the Karsky Sea. In as much as they are overlapped two-fold by Soviet territorial waters, as well as the Dmitry Laptev and Sannikov Straits, which unite the Laptev and Eastern Siberian Seas and belong historically to the Soviet Union. Not one of these stated straits, as is known, serves for international navigation. ${ }^{53}$

The assertion that the Sannikov and Dmitry Laptev Straits "belong historically to the USSR" did not specify whether this meant internal waters or the territorial sea. The note refers to the concepts of "territorial waters" and "internal waters" in parallel. As the former notion is not traditionally used in the law of the sea, it is helpful to see that Article 3 of the 1960 Statute used the concept of the territorial waters to denote the territorial sea. ${ }^{54}$

The Soviet authorities deemed the Burton Island a military vessel, and thus, subject to the requirement of prior authorization in both the territorial sea and the internal waters under Article 16 of the 1960 Statute in force at that time. Hence, the Soviets didn't need to specify at what parts of the NSR were the territorial sea and at what parts were internal waters. The lack of decisiveness of the USSR perhaps indicates that it could not find sufficient legal support for an internal waters claim concerning these straits.

If the USSR believed these straits had been historically overlapped with internal waters, this should have been affirmed when the opportunity arose, namely in the 1985 Decree. As such, the categorization of the waters in the Laptev and Sannikov Straits

${ }^{53}$ J. A. Roach and R. W. Smith, Excessive Maritime Claims (3rd edn, Martinus Nijhoff Publishers 2012): 312-313.

${ }^{54}$ The 1960 Statute. 
cannot be considered to reflect a clear and consistent intent to claim waters as historic internal waters.

Other Russian Arctic straits, including the traditional chokepoint, the Vilkitsky Strait, have never been the subject of a formal and, of course, a fortiori successful claim to historic internal waters.

\subsection{Maritime safety and environmental protection}

The third pillar of Soviet/Russian practice, with the practical effect of asserting control over Arctic navigation involved invoking coastal State jurisdiction to ensure maritime safety and environmental protection - associated with Article 234 of UNCLOS.

The first specific enactment to ensure maritime safety was the mandatory icebreaker assistance and pilotage requirements established for the Vilkitsky and Shokalsky Straits in $1965 .{ }^{55}$ In 1972 , these requirements were extended to the Dmitry Laptev and Sannikov Straits. ${ }^{56}$ The 1985 Soviet Notices to Mariners included the same requirements, applicable to all vessels within these four straits. ${ }^{57}$ Later, mandatory icebreaker assistance and pilotage requirements in these straits were included in Item 7.4 of the 1990 Regulations. Notably, the 2013 Rules do not include such a requirement.

${ }^{55}$ Franckx, note 47, at 156 refers to the Notices to Mariners, 1965, No 31, p. 10.

${ }^{56}$ Butler 1978, p. 174, reproduces the text of the Procedure for Navigation of Vessels in the Vilkitsky, Shokalsky, Dmitry Laptev and Sannikov Straits, Notices to Mariners 1972, Number 20.

${ }^{57}$ Franckx, note 47: 180-181. 
The first document where the USSR asserted special rights to regulate navigation in the entire NSR was the 1971 Statute on the NSR Administration. The Statute laid out a broad framework for the operation of the ANSR, enumerated its tasks and prerogatives, as well as mandated the ANSR to establish rules for navigation along the NSR ${ }^{58}-$ a task only completed by the Ministry of Merchant Marine of the USSR twenty years later. ${ }^{59}$

In light of the general nature of the 1971 Statute on the NSR Administration, it would be a strain to attribute it to any endorsement of claims to sovereignty or jurisdiction. ${ }^{60}$ It is, however, evident that the Statute constituted a marked shift towards the increased emphasis of the USSR on particular conditions of Arctic navigation, which required new approaches to ensure maritime safety and prevent vessel-source pollution. This led the USSR to endorse the idea behind Article 234 during UNCLOS III that took place in 1973-1982.

The first formal exercise of the jurisdiction to prescribe mandatory icebreaker assistance and pilotage requirements beyond the territorial sea only took place after the adoption of UNCLOS. Under Item 7.4 of the 1990 Regulations, the Marine Operation

${ }^{58}$ Article 3 (h) of the Decree On the Confirmation of the Statute of the Administration of the Northern Sea Route Attached to the Ministry of the Maritime Fleet, 16 September 1971, Sobraniye Postanovleniy Soveta Ministrov SSSR No. 17, p. 124 (1971 Statute on the NSR Administration).

${ }^{59}$ The 1990 Regulations.

${ }^{60}$ See discussion in Franckx note 47: 160-161. 
Headquarters ${ }^{61}$ obtained the mandate to prescribe mandatory icebreaker assistance and pilotage requirements within the entire geographical scope of the NSR, if necessary in light of navigational conditions. ${ }^{62}$

However, the legislative reform leading to the adoption of the 2013 Rules liberalized the regime of icebreaker assistance and pilotage. Items 10.6 and 23 of the 2013 Rules stipulate that the information on the necessity of icebreaker assistance be provided in the permission granted by the ANSR. Mandatory icebreaker assistance and pilotage requirements only arise under specific circumstances, but the ship owner is required to send an application anyway.

A significant feature of the mandatory icebreaker assistance and pilotage requirements in straits was that to comply with the requirements and pass through the straits, a formal request for assistance had to be made to the USSR. The effect in Soviet/Russian law of the failure to request assistance was that the proposed passage was an unauthorized passage of the vessel. This procedure avoided the necessity to defend the questionable Soviet legal posture on innocent passage.

Likewise, the enactment of the 1990 Regulations, the first instrument setting out detailed conditions for the use of the NSR by foreign ships, can be viewed as having the effect of 'opening' the NSR, but at the same time, the right to enter and navigate on the

${ }^{61}$ The Marine Operation Headquarters were under Item 1.7 of the 1990 Regulations defined as special navigational services of the Murmansk and Far East Shipping Companies, directly performing ice operations on the Northern Sea Route, under the general co-ordination by the Administration.

${ }^{62}$ Item 7.4 of the 1990 Regulations. 
NSR has been conditioned on prior authorization. ${ }^{63}$ While, in principle, other States enjoy rights and freedoms of navigation through the different maritime zones within the NSR, the USSR/Russia has assumed the discretion to determine whether a vessel is fit to enter and navigate the NSR. This has allowed the USSR/Russia to evade the question of other States' navigational rights through straits. As explained by Kolodkin, Markov and Ushakov, any vessel accepted for 'guiding' along the NSR automatically "receives the right of passage" through all its areas lying on the vessel's itinerary, including internal waters and territorial sea. ${ }^{64}$

This pillar of State practice has become of paramount significance for Russia's policy to control the NSR. The evolution of Soviet legislation to protect the fragile Arctic environment corresponded with a similar shift in international law. Soviet practice contributed, in part, to the development of international law, namely Article 234. Besides, the focus on the practical aspects of ensuring maritime safety and environmental protection has allowed Russia to deflect attention from the contentious issue of the navigational rights in the straits of the NSR. Otherwise, this pillar of Soviet/Russian State practice did not affect the applicability of navigational rights in the NSR. Instead, these measures should be seen as attaching conditions to the exercise of navigational rights.

${ }^{63}$ Item 2 of the 1990 Regulations. Also under Item 2 of the 2013 Rules, there is a requirement to obtain permission to enter and navigate the NSR. This requirement applies in the whole 'water area' of the NSR, encompassing internal waters, territorial sea and the EEZ.

${ }^{64}$ A. L. Kolodkin, V. Yu. Markov and A. P. Ushakov, "Legal Regime of Navigation in the Russian Arctic”, International Northern Sea Route Programme Working Paper 94-1997: 38. 


\section{The effects of Russian State practice on navigational rights}

The reliance on all these different tools and claims, in addition to the extreme conditions for Arctic navigation, have allowed the USSR/Russia to exercise de facto control over the NSR. What effect have all these claims and practices had on navigational rights and freedoms of other States under international law? In other words, what is the relevance of the situation de facto for the situation de jure?

\subsection{Does innocent passage apply in Russian Arctic straits?}

Having established that internal waters within straits enclosed by straight baselines do not constitute historic waters, the question remains whether they are subject to the right of innocent passage. Two issues can affect the answer.

The first relates to straight baselines adopted before UNCLOS entered into force. The question is whether such baselines qualify as established "in accordance with the method set forth in article 7". ${ }^{65}$ The second relates to the argument of the nonapplicability of the right of innocent passage in a strait overlapped with the territorial sea, but not having been used for international navigation without the consent of the coastal State. These two issues are addressed in order.

Regarding the specific situation of the Russian Arctic straits, it is not necessary to solve the temporal complication created by the adoption of baselines before UNCLOS entered into force. When the USSR established straight baselines in the Arctic in 1985, it was party to the 1958 TSCZ Convention and bound by its Article 5(2). Therefore, the right of innocent passage was unaffected by the designation of straight

\footnotetext{
${ }^{65}$ Article 8(2) of UNCLOS.
} 
baselines surrounding relevant Russian archipelagos in the Arctic (Novaya Zemlya, Severnaya Zemlya, Novosybirskie Ostrova).

The second limitation relates to the applicability of the right of innocent passage in straits where the right of innocent passage was not previously used without the USSR/Russia's consent. Under the 1958 TSCZ Convention, the right of innocent passage applies anywhere in the territorial sea, including straits, regardless of whether they are used for international navigation. ${ }^{66}$ Article 8(2) of UNCLOS repeats Article $5(2)$ of the 1958 TSCZ Convention, ${ }^{67}$ with minor adjustments necessary to reflect the developments in the law of the sea. As a result, both these provisions preserve innocent passage without the need for previous acceptance, acknowledgment or use. ${ }^{68}$

In summary, for navigation, it does not matter whether the Russian Arctic baselines are consistent with international law. The right of innocent passage under

${ }^{66}$ Article 16(3) and 16(4) of the 1958 TSCZ Convention.

${ }^{67}$ Notably, during the preparation for the 1958 TSCZ Convention, the draft, available in the Report of the ILC covering the work of its eighth session, 23 April-4 July 1956, Document A/3159, included Article 5(3), which would have preserved innocent passage in areas enclosed by new straight baselines only where the waters had normally been used by international traffic. The inclusion of this additional criterion was not successful, however.

${ }^{68}$ International Law Association (ILA), Baselines under the International Law of the Sea, Final Report 2018, https://www.ila-hq.org/images/ILA/DraftReports/DraftReport Baselines.pdf [21 January 2020]. As observed by K. Trümpler, “Article 8” in A. Proelss (ed), United Nations Convention on the Law of the Sea, A Commentary (C.H. Beck, Hart, Nomos 2017): 96, the applicability of the right of innocent passage under Article 8(2) appears in practice to render the status of waters enclosed by 'fresh' straight baselines to be more akin to the territorial sea than to internal waters proper. 
international law applied in all Russian Arctic straits, and it continues to apply there, despite Russia's current claim that internal waters cover them.

\subsection{Does transit passage apply in Russian Arctic straits?}

Turning to the question of whether Russian Arctic straits can qualify as 'straits used for international navigation' with the corresponding right of transit passage, this section first addresses the geographical and then the functional criterion.

Concerning the geographical criterion, an essential factor is the location of Russian Arctic baselines. The Barents, Kara, Laptev and East Siberian Seas are all overlapped with different maritime zones, including the EEZ and high seas. All straits mentioned above serve as a link between different seas (Barents, Kara, Laptev, East Siberian Seas), and the respective parts of Russian EEZ within these seas. This condition appears to satisfy the geographical criterion in the process of determining if a strait is a 'strait used for international navigation', as per the understanding of Part III of UNCLOS.

Concerning the functional criterion, the situation is slightly more complicated. The international use of the NSR, including its straits, had not started until $2010 .{ }^{69}$ Brubaker, writing in 2001, concluded that Russian Arctic straits could be considered 'non-international' ${ }^{70}$ The following section will highlight three points suggesting that sufficient 'international use' may accumulate to the point where the status of specific straits could be altered.

${ }^{69}$ Franckx and Boone note 32: 188-190.

${ }^{70}$ D. R. Brubaker, "Straits of the Russian Arctic" (2001) 32 (3) Ocean Development and International Law 263: 271. 
First, under international law, the right of innocent passage has applied in all Russian Arctic straits, regardless of the status of the waters overlapping them, and irrespective of the actual exercise of the right. Russia's current practice, i.e., the use of straight baselines does not rebut the presumption that innocent passage has been preserved.

Second, as the Russian requirement to obtain permission applies in the vast area of the NSR, encompassing different maritime zones, ${ }^{71}$ it is not specific enough to rebut the presumption that innocent passage applies within the straits. ${ }^{72}$ Therefore, even if one assumes for the sake of argument that Article 234 supports the requirement of prior authorization, ${ }^{73}$ it cannot serve as an argument to prevent transit passage from materializing. Russia may always claim full sovereignty over specific waters, clarifying at some point that innocent passage does not apply there, but the current permit scheme does not amount to such a claim. Besides, the political cost of such an action would be high, given the clarity about the relevant rules of the international law of the sea.

${ }^{71}$ See note 63 above.

${ }^{72}$ If one assumes that the requirement to obtain permission to enter and navigate the NSR does not affect the applicability of innocent passage in the territorial sea within the NSR, why would it affect the applicability of innocent passage in internal waters within the NSR?

${ }^{73}$ After all, this appears to be the best argument for Russia to maintain the authorization-based order of the NSR in place, see note 18 for evidence of Russia's practice. The discussion whether Article 234 allows for prior authorization lies beyond the focus of this article. Note, however, that in J. J. Solski, Russian Coastal State Jurisdiction over Commercial vessels navigating the Northern Sea Route, (PhD Thesis UiT the Arctic University of Norway 2019): 387-389 the author argues otherwise. 
Third, there is a question of 'use', and whether different modes of navigation, independent or with icebreaker assistance, would amount to one. Crucially, Russian Arctic straits are generally navigable with or without icebreaker assistance, depending on the ship's ice class and the navigational conditions. Moreover, although Russian legislation reserves icebreaker assistance to Russian icebreakers only, since the adoption of the current 2013 Rules, Russian legislation has allowed independent navigation, and many ships have availed themselves of this opportunity.

As such, current Russia's practice is unlikely to impede the process of an emerging regime of transit passage. It is thus reasonable to expect that independent navigation through straits will eventually contribute to the fulfillment of the functional criterion of use for international navigation. In any event, Russia has been marketing the NSR as an attractive alternative to other routes. If this aspiration materializes, at some point Russia will have to recognize the applicability of transit passage. At this moment, one can conclude that the applicability of transit passage in the Russian Arctic straits is in statu nascendi.

\section{The law of the sea on mandatory prior notification and pilotage for warships in lateral innocent passage}

Innocent passage applies in all Russian Arctic straits, and there are no special rules of international law, other than Article 234, that would grant additional jurisdiction to Russia to regulate navigation in the NSR. Russia cannot rely on Article 234 to regulate the passage of sovereign immune vessels, and therefore, the proposed regulations can be assessed in light of the generally applicable law of the sea, in the same way as elsewhere in the world. This section briefly discusses prior notification and pilotage.

Prior notification has long divided States. Regardless of numerous attempts to address the issue, the question of whether a coastal State has the right to require prior 
notification from high-risk vessels, such as warships or merchant ships carrying hazardous or noxious materials, including hazardous waste or radioactive materials, remains contentious. Churchill accurately notes that UNCLOS is "arguably unclear or ambiguous about whether a coastal State may require prior notification of the passage of ships carrying hazardous cargoes through its territorial sea as part of its powers under Article $21 "{ }^{74}$

When acceding to or ratifying UNCLOS, many States decided to attach declarations expressing their views on prior notification. Bangladesh, China, Ecuador, Egypt, Malta, Montenegro, Serbia all issued declarations under Article 310 in which they claim the right to require prior notification from some categories of ships.

On the other hand, some States felt the need to declare their opposition to the prior notification as incompatible with the right of innocent passage. These States included Germany, Italy, the Netherlands, and the UK. In a similar vein, the USA and the Soviet Union rejected the requirement of prior notification concerning innocent passage of all ships, including warships, regardless of cargo, armament or means of propulsion. Paragraph 2 of the 1989 USSR-USA Joint Statement reads:

All ships, including warships, regardless of cargo, armament or means of propulsion, enjoy the right of innocent passage through the territorial sea in accordance with international law, for which neither prior notification nor authorization is required.

These clear statements of position indicate that some States feel strongly about prior notification, arguing either for or against the right of a coastal State to require it.

${ }^{74}$ R. R. Churchill, “The Impact of State Practice on the Jurisdictional Framework Contained in the LOS Convention" in A. G. Oude Elferink (ed), Stability and Change in the Law of the Sea: The Role of the LOS Convention (Martinus Nijhoff Publishers 2005). 
Moreover, Russia has taken a clear position in this debate, which helped protect its flag State interests.

Pilotage involves the deployment of an experienced officer, usually on board, to guide the ship through exceptionally challenging waters. The crux of the measure lies in the ability of the pilot to share her/his navigational experience in the areas where such experience is vital for the safety of navigation. Traditionally, pilotage has been associated with ports and internal waters, where it can be made mandatory based on the port or coastal State's sovereignty. Some States have, however, adopted pilotage seaward of their internal waters.

Although pilotage is considered as one of the oldest means of facilitating navigation, international legal instruments have approached it with remarkable reserve. UNCLOS does not explicitly address pilotage in any of the provisions. Neither does SOLAS, despite its Chapter V entitled 'Safety of Navigation', where pilotage could arguably fit well. It is thus notable that even though States have long recognized the benefits of pilotage, including mandatory pilotage schemes, for the safety of navigation, the international community has not yet come to terms with how to specify the parameters of the international legal regime governing pilotage. Moreover, State practice shows that while compulsory pilotage can instigate much controversy for merchant ships exercising the right of innocent passage, it is much more contested for vessels enjoying sovereign immunity. Here one can recall US protests against a Finnish requirement to use pilot service when navigating in Finnish territorial waters, as well as US protests against similar requirements attempted by Italy in the Strait of Messina. ${ }^{75}$ Furthermore, the introduction of a compulsory pilotage scheme in the territorial sea in

\footnotetext{
${ }^{75}$ Roach and Smith note 53: 231.
} 
the Great Barrier Reef by Australia was successful pursuant to the recognition by the IMO that the waters in question required the services of a pilot to ensure safe passage. This was crucial for the appreciation that Australia's action did not hamper innocent passage. ${ }^{76}$ Norway has so far adopted the requirement of compulsory pilotage only within some parts of internal waters around Svalbard. ${ }^{77}$ These examples show that it is unlikely lawful for the coastal State to adopt compulsory pilotage for merchant ships exercising innocent passage unilaterally. The endorsement of the IMO, although providing no specific legal basis for the measure, helps to dispel doubts about proposed compulsory pilotage in the territorial sea. In instances where States proceeded unilaterally, other States are known to have protested against such a course of action. Also, the relevant legislation of both Australia and Norway exempts warships and other government vessels not employed on commercial service, which is consistent with UNCLOS.

\section{Conclusions}

The analysis of Russian State practice from a historical perspective allows the following conclusions. In pursuit of the general objective to exert control over the NSR, the USSR/Russia deployed different tools and claims. These were not part of a coordinated strategy but rather a result of opportunism and international legal

${ }^{76}$ D. R. Rothwell, "Compulsory Pilotage and the Law of the Sea: Lessons learned from the Torres Strait”, ANU College of Law Research Paper No. 12-06: 10.

${ }^{77}$ This follows from the official information by the Norwegian Coastal Administration, published at <http://www.kystverket.no/en/EN_Maritime-Services/Pilot-Exemption-

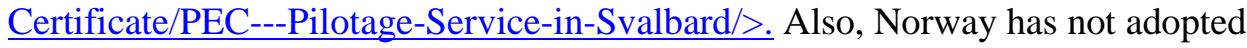
compulsory pilotage in other parts of the territorial sea. 
developments. As such, they were characterized by a careful prima facie reliance on the international law of the sea. The application of international legal instruments with relevance for the NSR was, usually, subject to specific deviations. These deviations were not accidental since the omissions or additions in domestic legislation implementing international law allowed for a gradual increase in the geographic scope and substantive extent of coastal State jurisdiction.

Yet the USSR/Russia never endorsed broad sovereignty-related theories regarding the regime of navigation, such as the application of the sector theory to marine expanses, or broad historic claims, both of which were advocated for by Soviet academics. Arctic baselines drawn in 1985 confirmed that vast expanses of the Kara, Laptev and East Siberian Seas were comprised by the high seas, and the $200 \mathrm{~nm}$ EEZ that followed. Moreover, the right of innocent passage applies in all Russian Arctic straits because they were comprised of the territorial sea before their enclosure with straight baselines.

To be sure, the USSR had a choice not to ratify UNCLOS and claim sovereignty over its Arctic sector. However, this course of action likely would not have benefited or advanced Soviet interests. Even specifically concerning the Arctic, the USSR/Russia walked out of UNCLOS III with Article 234, as well as the procedure to obtain recognition for sovereign rights over a sizeable continental shelf. It is doubtful that Russia would ever have been able to garner international recognition for claims having a similar effect in the Arctic had it not joined UNCLOS, not to mention all the other rights and freedoms that the USSR secured outside the Arctic.

The liberalization of the legal regime of navigation in the NSR can only partially be explained by the effort to make the NSR attractive for international use. Another part 
of the equation is respect for the international law of the sea. In this context, it is not entirely surprising that the gradual clarification of the Russian position can sometimes backfire, leaving challenging gaps, such as the question of the navigational regime for sovereign immune vessels. It is difficult to predict how determined Russia is to adopt new regulations for the innocent passage of ships enjoying sovereign immunity within the NSR. At the time of writing, nine months have already passed since the draft legislation was published for consultations.

The impression is that the primary purpose of the draft is to send a strong political signal to deter further challenge to Russia's somewhat ambiguous claims. Even without having been signed, the draft received much publicity in Russian and foreign media, at times even creating a wrong impression that it has entered into force. ${ }^{78}$ Here one can also recall the statement by the Chief of the General Staff of the Armed Forces of the Russian Federation Valery Gerasimov, who at the meeting with foreign military attaches said

[O]ur Armed Forces can fully ensure the safety of navigation in the waters of the Northern Sea Route, and therefore there is no need to find warships of other countries in this sea corridor. ${ }^{79}$

78 The media - here it is not necessary to refer to examples of sub-optimal reports or diagnose why they came about - were quick to pick up a story without due verification of facts, which would require an understanding of the Russian language and the legislative process in that country.

${ }^{79}$ O. Vozhyeva, "Eksperty otsenili vozmozhnost' voyennogo konflikta v Arktike”, 18 December 2019, MKRU, https://www.mk.ru/politics/2019/12/18/eksperty-ocenilivozmozhnost-voennogo-konflikta-v-arktike.html [21 January 2020]. 
In any event, the adoption of such regulations would undoubtedly be very controversial and unlikely to garner international recognition. Russia may amend its current legislation, but even then, the question would remain about enforcement. 